\title{
Media Pengembangan Bakat Dan Ketrampilan Santri Pondok Pesantren Nur Fadhilah Dalam Pengoptimalan Sumber Daya Manusia
}

\author{
Mugi Nurcahyo \\ Pengembangan Masyarakat Islam, Institut Agama Islam Sunan Giri ( INSURI ) Ponorogo. \\ mugeknur100@gmail.com
}

\begin{abstract}
Absract : empowerment of students and youth in a boarding school that is in the midst of society as an effort to develop human resources in fields that may someday students already be in the community. The reason for the HR development program being implemented in this Islamic boarding school is to remember the human resources that are owned or the potential that is in vain at a young age who should have gained experience as a provision for the next life which is now being replaced with things that are not important. For this reason, this Islamic boarding school implements the program. The approach or research method used in the empowerment is education carried out by Islamic boarding schools to students and youth through skills training and social sciences. The result of this program is to train local students and youth, apart from getting knowledge of the Islamic boarding school, they also get provisions which can then be applied in their respective communities.
\end{abstract}

Keywords: empowerment of youth and students, islamic boarding schools Nur Fadhilah

Abstrak : pemberdayaan santri dan pemuda di dalam sebuah pondok pesantren yang berada di tengah masyarakat sebagai upaya dalam mengembangkan SDM pada bidang yang mungkin nanti kelak santri sudah berada di masyarakat. Program pengembangan SDM yang diterapkan di pondok pesantren ini, yaitu mengingat SDM yang di miliki atau potensi yang sia-sia di usia muda yang harusnya sudah mendapat pengalaman untuk bekal masa depan terganti dengan hal yang kurang penting, untuk itu pondok pesantren ini menerapkan program tersebut. Pendekatan atau metode penelitian yang di gunakan dalam pemberdayaan tersebut ialah edukasi yang di lakukan oleh pondok pesantren kepada santri dan pemuda melalui pelatihan ketrampilan dan ilmu sosial. Hasil dari program ini adalah untuk melatih santri dan pemuda setempat selain mendapat ilmu pengetahuan pondok, mereka juga mendapat bekal ilmu dan pengalaman yang kemudian dapat mengaplikasikanya di masyarakat masing-masing.

Kata kunci : pemberdayaan pemuda dan santri, pondok pesantren Nur Fadhilah

\section{A. Pendahuluan}

Kelurahan Dadahan Polorejo, Kec. Babadan, Kabupaten. Ponorogo merupakan salah satu daerahdi Ponorogo sebelah utara yang mana daerah ini berada di tengah tengah sawah dan memiliki potensi yang masih belum ada pengelolaanya, terutama banyak dari kalangan anak muda yang masih pengangguran dan kurang dalam ketrampilan. Semenjak di dirikanya sebuh yayasan pondok pesantren nur fadhilah yang notabenya berada di tengah masyarakat menjadikan masyarakat tergabung dan antusias mulai dari awal pembangunan sampai saat ini seperti membantu tenaga pikiran serta ikut memberikan makan tukang yang bekerja di 
pembangunann pondok pesantren ini. Dari sinilah awal mulanya pondok pesantren ini bisa bergabung jadi satu dengan masyarakat bukan hanya dari kalangan orang tua tetapi dari pemuda juga banyak yang berpartisipasi ikut kegiatan di pondok pesantren ini seperti mengaji, pelatihan-pelatihan, serta tenaga.

Lebih dari sekedar interaksi antara kyai dan santri, bahkan pesantren juga berinteraksi dengan masyarakat sekitar. Interaksi tersebut pada akhirnya mengalami transformasi makna dan peran, yakni mengarahkan kepada perubahan, pengembangan dan keberdayaan santri, yang diwujudkan dalam bentuk yang beraneka ragam, termasuk ke dalam kepedulian terhadap masalah yang dihadapi khususnya masalah pemberdayaan SDM.Terkait dengan masalah SDM, pondok pesantren dengan eksistensinya sebagai salah satu lembaga yang mempunyai pengaruh kuat untuk memberdayakan masyarakat melalui program-program yang ditawarkan oleh pondok pesantren baik yang berkenaan dengan pendidikan keagamaan sampai kepada pelatihan, hal ini yang memotivasi beberapa pondok pesantren untuk mencoba memadukan sistem pendidikan agama dengan pendidikan ketrampilan. Selain santri di didik untuk menadalami ilmu agama, pondok pesantren juga memberikan pelatihan kepada para santrinya melalui unit kegiatan pondok. Disinilah potensi pondok pesantren, yakni dengan melakukan perannya sebagai lembaga kemasyarakatan untukmeningkatkan inisiatif dan kreatif dari masyarakat sebagai sumber utama pembangunan dan yang menekankan kesejahteraan material dan spiritual masyarakat sebagai tujuan dari proses pembangunan (Taufik Abdullah, 1996).

Pondok pesantren dengan berbagai harapan dan predikat yang diletakkan padanya, sesungguhnya berujung pada tiga fungsi utama, yaitu pertama, sebagai pusat pengkaderan pemikir-pemikir agama (center of excellence). Kedua, sebagai lembaga yang mencetak sumber daya manusia (human resource). Dan ketiga, sebagai lembaga yang mempunyai kekuatanmelakukan pemberdayaan pada masyarakat (agent of development) (Suhartini, 2009).Corak pendidikan Islam tertua yang telah memberikan ragam istimewa dalamkeberagaman masyarakat muslim Indonesia. Corak dan ragam yang dimaksud di sini antara lain karena ia tidak hanya menjadi tempat belajar, tetapi juga menjadi pola hubungan interaksi kyai dan santri terjalin amat erat dan nilai-nilai keagamaan inilah yang menjadi dasar pertimbangan penyelenggaran pondok pesantren. Pondok pesantren sebagai salah satu basis bantuan sosial dan pusat pendidikan keagamaan yang dapat memberikan motivasi bagi masyarakat yang berada di sekitarnya (Ebah Suaiybah,2009).Pondok pesantren merupakan lembaga pendidikan untuk mencetak manusia yang religius dan mandiri. Para santri didik dan 
dibina dalam meningkatkan jiwa keterampilan. Dengan demikian, pesantren dapat menjadi pusat kelembagaan ekonomi,bagi warganya di dalam maupun di luar pesantren (Ahmad Faozan, 2006).

Fungsi lainnya yaitu sebagai instrumen untuk tetap melestarikan pengajaran Islam di bumi Nusantara, karena pondok pesantren mempunyai pengaruh yang kuat dalam membentuk dan memelihara kehidupan sosial, kultural,politik, keagamaan, dan sebagainya (Didin Hafhiduddin,1998).Perkembangan teknologi informasi dan komunikasi yang sangat pesat memungkinkan terjadinya pertukaran informasi tanpa batasan ruang dan waktu. Pertukaran informasi dapat berupa pengetahuan, teknologi, seni, budaya dan lain lain. Hal itu dapat memberikan hal positif dan negatif terhadap pembangunan bangsa indonesia, contoh: pengaruh positif yang di berikan adalah kemajuan dalam bidang teknologi serta informasi dan ilmu pengetahuan dapat dengan mudah di dapatkan, tetepipermasalahan yang terjadi adalah tidak semua informasi dari dunia luar tersebut cocok dengan karakter bangsa. Pertukaran informasi juga memungkinkan terjadinya pertukaran budaya dari dunia luar dengan budaya indonesia (Paisal Anwar S.H.,M.H, 2019).Pondok pesantren ini menjadi solusi di tengah masyarakat untuk menyaring dan menambah wawasan untuk para pemuda menambah ilmu kerohanian serta para santri mendapat kesempatan bergabung dengan masyarakat untuk mendapatkan pengalaman ilmu kemasyarakatandan dapat mengamalkan ilmu yang sudah di dapatkan.

Permasalahan atau potensi aset yang harus di kembangkan atau perlu adanya genjotan tindakan. Seperti pelatihan dan kegiatan yang bermanfaat untuk masa depan masing-masing santri dan pemuda. Di sini juga di dirikan oleh yayasan pondok pesantren nur fadhilah yaitu sebuah lembaga pendidikan madrasah diniyah untuk anak-anak masyarakat setempat, ini memberikan banyak manfaat kepada sebagian santri yang sudah mampu dalam mengamalkan ilmu, yaitu dapat ikut menjadi tenaga pengajar. Kegiatan madrasah ini diadakan setiap hari kecuali hari jumat dan minggu. Di samping itu pembangunan untuk asrama pondok masih berlanjut, bagi santri yang tidak ikut tergabung di daam pengajaran madin sebagian ikut di pembangunan itung itung untuk mendapatkan tambahan uang jajan sekaligus untuk mengabdi kepada pondok, ada juga dari kami yang hanya mukim dan ngaji saja dan memilih kegiatan di luar seperti kerja ataupun sengaja mencari pengalaman di luiar pondok.

Kegiatan kegiatan pondok pesantren ini yang khusus bagi santri hanya di adakan pada malam hari saja seperti ngaji sorogan, ngaji kitab kuning, pelatihan tahlil, dan 
pelatihan qira' di mulai sehabis bakda magrib sampai jam 10 malam dan di lanjut lagi bakda subuh sampai jam 7 pagi di serambi masjid yang di kelola oleh masyarakat, mengingat pembangunan masjid yang ada di pondok ini masih belum bisa di tempati . Selain santri di dalam kegiatan ini pemuda setempat juga ikut di dalamnya.

Hasilnya santri dan pemuda yang saling berkolaborasi dengan lingkungan masyarakat serta pondok pesantren ini dapat merasakan manfaatnya secara langsung bukan hanya bisa belajar di ruanglingkup pondok tetepi juga mengamalkan langsung ilmu kepada masyarakat dengan pemuda setempat, dan secara tidak langsung kegitan ini adalah gambaran bentuk dari sebuah kpm. Melalui pendekatan ABCD (Asset Based Community Development) memungkinkan peneliti, santri, dan pemuda bekerja sama dalam menggali asset-aset yang ada di pondok pesantren nur fadhilah dan mengoptimalkan asset tersebut, yang dimulai dari mengenali asset, merencanakan, dan mengevaluasi program guna kemajuan sdm santri dan para pemuda.

\section{B. Metode Pendampingan}

Pendampingan pengabdian masyarakat menggunakan metode pendekatan ABCD (Asset Based Community Development) yang mengutamakan pemanfaatan aset dan potensi yang ada di sekitar dan dimiliki oleh masyarakat / obyek yang di jadikan bahan penelitian pemberdayaan masyarakat. Metode ABCD (Asset Based Community Development) yang di jadikan sebagai pendekatan KPM pada tahun ini saya cocokkan dengan aset yang ada di lingkungan sekitar yaitu ranah pondok pesantren agar-aset potensi SDM santri dan pemuda sekitar bisa tersalurkan dan bermanfaat untuk kedepanya. Pendekatan ini lebih memilih cara pandang bahwasanya dalam masyarakat pasti memiliki suatu yang dapat di berdayakan / potensi yang terpendam yang memiliki manfaat dan nilai.

Metode penelitian berbasis asset ABCD (Asset Based Community Development) adalah tentang membuat sesuatu hubungan. Ini adalah tentang menemukan suatu hubungan yang ada di lingkungan, dan membantu untuk membangun hubungan yang baru dengan sekitarnya asset dapat di manfaatkan (Al Barrett, 2013).

pendekatan berbasis asset adalah perpaduan antara metode bertindak dan cara berfikir tentang pembangunan. Pendekatan ini merupakan pergeseran yang penting sekaligus radikal dari pandangan yang berlaku saat ini tentang pembangunan serta menyentuh setiap aspek dalam cara kita terlibat dalam pelaksanaan pembangunan melihat metode lainya yang 
mengembangkan masyarakat melalui masalah yang akan di atasi kemudian memulai proses interaksi dengan analisis pohon masalah, pendekatan berbasis asset ini berfokus pada sejarah keberhasilan yang telah di capai yaitu para pembaru atau orang orang yang telah sukses dan menghargai potensi melakukan mobilisasi serta mengaitkan kekuatan dan aset yang ada (Christopher Dureau, 2013).

Terdapat tuju tahapan kegiatan yang dilakukan dalam kegiatan pendampingan ini yaitu diawali dengan persiapan dan kesiapan dengan segala sesuatu yang akan di perlukan dalam penelitian. Kedua melakukan identifikasi asset / kekurangan, memcatat segala sumber daya yang di miliki beserta kelebihan dan kekurangan masing masing aset yang ada. Ketiga merancang cita-cita merupakan impian atau harapan. Keempat menentukan terwujud cita-cita merupakan usaha atau kesungguhan masyarakatdalam memproses sebuah keinginan atau citc-cita dalam penelitian. Kelima melibatkan partisipasi masyarakat dalam kegiatan. Keenam identifikasi keberhasilan program yang berisi evaluasi kegiatan dan ke tuju di tutup dengan penulisan laporan.

\section{Hasil Dan Pembahasan}

Pondok pesantren nur fadhlah desa polorejo kec. Babadan ponorogo ini adalah salah satu pondok yang dapat di katakana masih baru karena masih berdiri tahun 2019 silam dan sekarang sudah menginjak kurang lebuh 2 tahun. Berdirinya pondok pesantren dimelatar belakangi karena ada pemekaran dari pondok pesantren al idris banyudono ponorogo. Kebanyakan dari santri yang tergabung di pondok ini adalah dari kalangan mahasiswa. Tujuan dan maksud di dirikanya pondok pesantren nur fadhilah ini adalah untuk mengembangkan syiar agama yang lebih luas lagi dan mengembangkan bakat dan ketrampilan santri yang tergabung di dalamnya memiliki pengalaman dan dapat mengembangkan potensi sdm yang akan di gunakan kelak sudah terjun langsung ke masyarkat, bukan hanya wadah untuk menimba ilmu agama saja yang di harapkan dari pondok pesantren ini tetapi juga untk memdorong aset yang di miliki santri agar bisa jerjun langsung ke masyarakat, letak pondok pesantren ini yang berada di tengah pemukiman masyarakat yang menjadi latar belakang santri bisa terjun langsung ke masyarakat, bukan hanya melatih sosial tetapi sebagai ajang santri untuk sedikit banyak mengamalkan ilmu kepada masyarakat.

Pondok pesantren ini yang di asuh oleh kh. Tajul mujahidin, beliau adalah salah satu dosen kampus insuri ponorogo, beliau juga adalah putra dari kh habib masud yaitu pendiri 
serta pengasuh pondok pesantren darul mutaqin yang berada di Karangan Jati prahu Trenggalek. Beliau pernah menjadi santri di masa muada dan mengabdi di pondok pesantren al idris ponorogo dan akhirnya di angkat untuk menjadi pengasuh selama beberapa priode, tidak hanya berhenti di situ saja beliau mengembangkan agama setelah mendirikan rumah di kediaman istri atau yang di bikin pondok pesantren ini, dan menyerahkan kepengasuhan di pondok pesantren al idris kepada putra sah dari keluarga kh idris. Pembangunan sampai saat ini terus berlanjut, selama 2 tahun ini sudah berdiri 3 bangunan yaitu asrama putra, masjid, dan juga ndalem.

Santri yang tergabung terbagi dari santri local atau pemuda dari masyarakat sekitar dan santri luar daerah yang menjadi potensi daerah dalam mewadahi penyaluran bakat potensi yang perlu di kembangkan untuk pembangunan masa depan pemuda. Sebagaimana tujuan awalnya lembaga ini di dirikan untuk menaungi masyarakat dalam pengembangan sdm pemuda dalam pengembangan penyiaran agama. Selama ini penyiaran agama di lingkungan masyarakat ini belum tetata dengan benar, semenjak adanya lembaga ini menjadikan potensi bagi masyarakat untuk terus berkembang menunjukan jati dirinya. Asset yang di kembangkan dari pondok pesantren ini meliputi,

1. Kegiatan belajar ilmu agama santri ( ngaji ) merujuk pada aktivitas membaca Alqur'an atau membahas kitab-kitab oleh penganut agama islam. Aktivitas ini dalam agama islam termasuk ibadah dan orang yang melakukanya akan mendapatkan ganjaran dari allah. Secara Bahasa mengaji memiliki arti belajar atau mempelajari (KBBI,1996). Kegiatan ini di aplikasikan di pondok pesantren ini pada waktu bakda magrib sampai jam 10 malam, dan juga setelah bakda subuh. Memfokuskan kegiatan pondok di praktikkan di malam hari karena belum ada pendidikan formal untuk menaungi santri, sehingga santri pada saat pagi sampai sore diakukan untuk kegiatan sekolah di luar pondok, bukan hanya itu saja bagi santri yang tidak kuliah ataupun sekolah ada juga yang bekerja dan mengabdi di pondok.

2. Madrasah diniyah ( madin ) adalah suatu lembaga pendidikan keagamaan pada jalur luar sekolah yang di harapkan mampu secara terus menerus memberikan pendidikan agama islam kepada anak didik yang tidak terpenuhi pada jalur sekolah yang di berikan melalui system klasikal serta menerapkan jenjang pendidikan (Depag, 2000). Madrasah diniyah adaah madrasah yang seluruh mata pelajaranya bermaterikan ilmu-ilmu, yaitu fiqh, tafsir, tauhud, dan ilmu-ilmu agama lainya (Header Amin,dkk, 2004).Sengaja lembaga nur fadhilah mendirikan 
sebuah madin untnk menaungi anak anak lingkungan sekitar agar potensi aseet yang ada di masyarakat dapat di kelola dengan baik. Madin yang ada di sini juga memenfatakan santri sebagai tenaga pengajarnya sebagai ajang santri dalam mengamalkan ilmu.

3. Tahlilan adalah ritual atau upacara selamaatan yang di lakukan sebagai umat islam, kebanyakan di Indonesia dan kemungkinan di Malaysia, untuk memperingati dan mendoakan orang yang telah meninggal yang biasanya dilakukan pada hari pertama kematian hingga hari ke tuju, dan selanjutnya di lakukan pada hari -40,ke-100,ke satutahun pertama, kedua, ketiga, dan seterusnya. Ada pula yang melakukan tahlilan pada hari ke-1000 (Zainudin, 2015).Di sini santri mempraktekkan kegiatan yaitu bagaimana tatat cara menjadi imam tahlil pada sebuah acara mualai dari membuka sampai akhir dari sebuah acara, kegiatan ini rutun setiap hari jumat pagi secara bergilir dan di dampingi langsung oleh abah KH Tajul Mujahidin selaku pengasuh pondok untuk melatih dan membimbing kegiatan ini.

4. Kegiatan mengabdi sebagai tukang bangunan, cara untuk melatih kemandirian santri terhadap pengembangan sdm, selain mendapat ilmu pondok mungkin dapat berguna juga untuk masa depan dan tujuan ini bermanfaat untuk mengisi waktu masa muda untuk mendapat pengalaman.

Dari hasil kegiatan-kegiatan yang sudah berjalan di pondok pesantren ini santri sudah ada perkembangan pada bidang sosial kemasyarakatan yaitu bisa berinteraksi langsung dengan masyarakat melelui bakat dan ketrampilan. Menjadikan asset masyarakat untuk memajukan daerahnya semakain ramai dengan kegiatan yang positif, dengan kata lain dengan adanya pondok pesantren yang berbasis seperti ini akan mengundang banyak santri untuk bergabung melalaui sambung lidah atau getok tular dari masyarakat. Dengan demikian pengelolaan dam managemen santri dalam pengembangan bakat dan ketrampilan perlu di utamakan dan adanya penegasan yang lebih baik lagi dari pengurus serta yayasan ataupun pengelola. Management adalah proses bekerjasama antara individu dan kelompok serta sumber daya lainya dalam mencapai tujuan, organisasi adalah sebagai aktifitas manajement. Dengan kata lain, aktivitas menejerial hanya ditemukan dalam wadah sebuah organisasi, baik organisasi bisnis, sekolah, dan juga lainya (Syaifudin, 2005).Istilah management sudah popular dengan kehidupan organisasi. Dalam makna yang sederhana " management" 
diartikan sebagai pengelolaan. Suatau proses meneta atau mengelola organisasi dalam mencapai tujuan yang di inginkan dipahami sebagai management (Syaifudin,dkk, 2011).

Ada bermacam macam definisi management, dan tergantung dari sudut pandang, keyakinan, dan konferhensif dari para pendefenisi, di antara lain: kekuatan menjalnkan sebuah perusahaan dan bertanggung jawab atas kesuksesan atau kegagalanya. Ada pula pihak lain yang berpendapat bahwa, management adalah tindakan memikirkan dan mencapai hasilhasil yang di inginkan melalui usaha-usaha kelompok yang terdiri dari tindakan mendayagunakan bakat-bakat manusia dan sumber daya manusia secara singkat orang pernah menyatakan tindakan managemen adalah sebagai tindakan merenmcanakan dan mengimplementasikan (Winardi, 1993). Management adalah ilmu dan seni mengatur proses pemanfaatan sumber daya manusia dan sumber-sumber lain secara efektif dan efisien untuk mencapai suatu tujuan. Management merupakan sebuah proses kerjasama untuk mencapai tujuan bersama. Sementara Thoha, berpendapat bahwa management diartikan sebagai " suatu proses pencapain tujuan organisasi lewat usaha orang lain" (Miftah Thoha, 1995).Selain managemen yang benar pondok dan yayasan sama-sama memiliki tujuan yang sama yaitu mendidik generasi yang lebih unggul lewat siar agama, tidak luput dari santri yang tergabung di dalamnya juga saling imbal balik dengam masyarakat karena saling menguntungkan bagi keduanya.

Dari adanya asset ini maka analisis dari kegiatan yang ada di pondok pesantren ini yakni dalam mengembangkan sdm dan ketrampilan dapat terlaksana dan terorganisis atau tertata dan di harapkan dapat menghasilkan sdm yang unggul untuk meraih masa depan.

\section{Kesimpulan}

Berdasarkan hasil penelitian lapangan pendampngan kepada santri dan pemuda dalam mengembangkan SDM ketrampilan yang di adakan di dalam bidang keagamaan pondok pesantren dengan menggunakan metode ABCD (Asset Based Community Development). Keberhasilan tidak luput dari keaktian dari masyarakat serta management pengelolaan yang bagus dari yayasan pondok pesantren. Sehingga daripada itu manajemen penataan yang di katakan juga masih baru cukup berhasil dalam menjalankan program tersebut. Dengan adanya pondok pesantren ini hubungan antara masyarakat dengan pondok pesantren ini semakin erat, dan juga lingkungan masyarakat menjadi lebih ramai. Guna untk menunjukan aseet wilayah pemerintah setempat juga memberikan pandangan serta perhatian dari pembangunan pondok pesantren ini. Mencetak generasi yang berdayaguna di masa depan 
melalui pengembangan SDM potensi santri dan pemuda adalah hal untuk memanfaatkan aseet, karena kebanyakan pemuda sekarang masih kurang dalam ketrampilan dan ilmu yang bermanfaat. Begabung dengan msyarakat juga melatih ilmu sosial santri dalam pengamalan ilmu yang jarang didapatkan di masa sekarang. Tidak luput dari pengembangan ilmu untuk anak anak yang ada di masyarakat setempat sengaja membuka madrasah diniyah untuk menampung anak anak untuk mengurangi pengaruh dari perkambangan zaman pada saat ini. Bukan hanya itu saja pengalaman pengalaman yang di dapatkan di pondok pesantren di harapkan bisa bermanfaat bagi santri, pemuda, anak anak, kelak dan kunci meraih masa depan.

\section{Daftar pustaka}

Al Barrett Asset-Based Comunity Development : A Theologichal Reflection, ( Birmingham Vicar Of Hodge Hill Church, 2013), Hal.5.

Christopher Dureau, Pembaru Dan Kekuatan Lokal Untuk Pembangunan, ( Canberra: Australian Community Development And Civil Society Strengthening Schame ( Access) Phase ii,2013), Hal. 39.

Dapartemen Pendidikan Dan Kebudayaan Nasional, Kamus Besar Bahasa Indosesia, Jakarta: Balai Pustaka, 1996, h. 747

Dapartemen Agama RI, Pedoman Penyelenggaraan Dan Pembinaan Madrasah Diniyah (Jakarta: Depag, 2000), H. 7.

Didin Hafhiduddin, Dakwah Aktual, cet. I (Jakarta: Gema Insani, 1998), 120.

Disarikan dari Ahmad Faozan, "Pondok Pesantren dan Pemberdayaan Ekonomi", Jurnal Ibda', Vol. 4, No. 1 (Juni, 2006): 1-12.

Ebah Suaiybah, "Pemberdayaan Ekonomi Santri Melalui Penanaman Jamur Tiram (Studi Kasus di Pondok Pesantren Al-Ma'muroh Desa Susukan Kecamatan Cipicung Kabupaten Kuningan Jawa Barat)", Skripsi (Yogyakarta: UIN Sunan Kalijaga, 2009), 4.

Header Amin, El-Saha Islam, Peningkatan Mutu Terpadu Pesantren Dan Madrasah Diniyah (Jakarta:Diva Pustaka, 2004),H. 39.

Miftah Thoha, Kepemimpinan Dalam Management, Cet II (Jakarta: Raja Grafindo Persada, 1995), H. 8. 
Pemuda Indonesia Dan Pembangunan Sumber Daya Manusia Masa Kini," Paisal Anwar S.H.,M.H-Opini, 10,2019, berita cianjur.com

Suhartini, "Problem Kelembagaan Pengembangan Ekonomi Pesantren", dalam Pustaka Pesantren (ed.), Manajemen Pesantren (Yogyakarta: LKIS, 2009), 233.

Syaifudin \& Nurmawati, Peengelolaan Pendidikan Mengembangkan Ketrampilan Management Pendidikan Menuju Sebuah Efektif (Medan: Perdana Publishing, 2011), H. 16.

Syaifudin, Management Lembaga Pendidikan Islam (Jakarta: Ciputat Press, 2005), H.41.

Tentang peran pesantren yang demikian, lihat Taufik Abdullah, Islam dan Masyarakat (Jakarta:LP3Es, 1996), iii.

Winardi, Asas-Asas Management, Cet III ( Bndung: Alumni, 1993), H. 4.

Zainudin ( 26 september 2015 ). "tahlilan dalam prespektif ( historis, sosiologis,pisikologis,antropologis )“.UIN maulana Malik Ibrahim Malang. 